И. Ю. Токарева

\title{
ВОПРОСЫ ПРОЕКТИРОВАНИЯ ЛИНГВОКУЛЬТУРОЛОГИЧЕСКИХ ПРИРАЩЕНИЙ В ШКОЛЬНОМ КУРСЕ РУССКОГО ЯЗЫКА
}

Токарева I. Ю. Питання проектування лінгвокультурологічних прирощувань у шкільному курсі російської мови.

У статті розкрито сутність лінгвокультурологічних прирощувань до основного матеріалу у процесі вивчення російської мови, розглянуто питання проектування залучення лінгвокультурологічного матеріалу.

Ключові слова: навчання мові, мова, культура, культурно-мовна компетенція, проектування.

Токарева И. Ю. Вопросы проектирования лингвокультурологических приращений в школьном курсе русского языка.

В статье излагается сущность лингвокультурологического приращения к основному материалу при изучении русского языка, рассматриваются вопросы проектирования включения лингвокультурологического материала.

Ключевые слова: обучение языку, язык, культура, культурно-языковая компетенция, проектирование.

Tokareva I. Y. The inclusion cultural information in a school course Russian language.

The article describes the essence linguistic and cultural increment to the base material in the study of the Russian language, the issues of design incorporating linguistic and cultural material.

Key words: language learning, language, culture, cultural and linguistic competence, design. 
Учёные отмечают, что интерес школьной методики к концептуальной картине мира народа, его менталитету, этнокультурным особенностям, традициям обусловливает «востребованность в сфере обучения языку таких понятий, как концепт, концептуальный анализ, картина мира, менталитет, традиции речевой культуры народа, языковое сознание» [2, с. 248]. Формирование культурно-языковой компетенции связано не только с получением знаний из области лингвокультурологии, но и воспитанием духовного человека, опирается на развитие ряда смежных способностей: культуроведческой, коммуникативной, языковой и др. «Будущему выпускнику необходимы знания культурно-языкового характера, способные создать фундамент для совершенствования речевой индивидуальности» $[9, \mathrm{c}$. 176]. В этом ключе образование осмысляется как процесс вхождения человека в культуру [10]. Решение названной методической задачи возможно в рамках как традиционных, так и новых дисциплин. В США разработана учебная программа «Назад к истокам», в основе которой лежат культурноисторические дисциплины. В нашей стране формирование культурноязыковой компетенции осуществляется в рамках преподавания русского языка, литературы, элективных курсов. А. Д. Дейкина отмечает: «Задача формирования духовно-нравственной культуры учащихся ... в перспективе должна решаться в школе как государственном институте формирования личности и самосохранения нации» [6, с. 11].

Концепция модернизации российского образования опирается на директивы формировать у учащегося соответствующие компетенции. Важность формирования культурно-языковой компетенции обусловлена недостаточным уровнем лингвокультурного образования современного ученика, слабым интересом к родному языку и культуре. Теоретики лингвокультурологии Д. Гудков и Е. Скороходова отмечают по этому поводу: «Именно речевая практика лингво-культурного сообщества определяет жизнь языка, его развитие или деградацию. Поэтому и удивляет благодушие тех специалистов, которые, признавая массу негативных явлений в речи современных носителей русского языка, продолжают утверждать, что этому языку ничего не угрожает. В определённом смысле они, конечно, правы: склад остаётся на месте, то, что на нём было, пребывает на своих местах, никуда не исчезает, просто перестаёт существовать для общества» [5, с. 15].

Обращение к лингвокультурным основам находим ещё в трудах Ф. Буслаева, который говорил, что в слове сходится всё, чем крепится нравственная жизнь народа (Буслаев Ф.И. «Народный эпос и мифология»). Однако методисты ещё не в достаточной мере разработали ○ И. Ю. Токарева, 2015. 
технологии нравственного и общекультурного развития личности с опорой на изучение ресурсов родного языка.

Актуальность включения в методику обучения русскому языку как родному культурного компонента отмечает Н. Шанский, А. Дейкина.

Л. Новикова так определяет актуальность и перспективность лингвокультурологического подхода в современной методике преподавания словесности: «Это важное направление современной методики, представляющее собой совокупность теоретических положений, практических наработок, экспериментальных исследований, позволяющих учителю стать Посредником между Учеником, с одной стороны, Культурой и Языком - с другой, а учащимся приобщиться к культуре народа, воспринять, эмоционально пережить и присвоить базовые ценности национального и общечеловеческого характера, которые, включаясь в структуру личности, становятся ценностным базовым образованием и созидают человеческое в человеке» $[7$, с. 7].

Задача изучения связей языка и культуры поставлена перед современной методической наукой. Данное направление определено как приоритетное в обучении русскому языку [1, с. 229]. Разработаны методические рекомендации научной группой под руководством А. Дейкиной «Формирование культуроведческой компетенции учащихся при обучении русскому языку» (2005). В рамках этой проблемы написаны диссертационные работы («Лингвокультурологический и лингвокраеведческий потенциал системы формирования языковой личности школьника. 5-6 классы» Е. Пархомова; «Учебный лингвокультурологический словарь «Концепты духовности русской языковой картины мира как основа формирования концептосферы учащихся на уроках русского языка» Т. Кобякова и др.), предложены интересные проекты, например, программа элективного курса «Язык. Культура. Общество», созданная Т. Новиковой, системы упражнений, разработанные Н. Мишатиной, Л. Муллагалиевой, Л. Саяховой и мн. др. Так, Н. Мишатина предлагает формировать языковую личность учащегося на основе лингвоконцептоцентрического подхода, заключающегося в изучении концептов русской культуры. Однако комплексного теоретического и практического освещения проблема культурно-языковой компетенции ещё не получила.

Несмотря на усилия учёных обеспечить методическую поддержку процессу формирования культурно-языковой компетенции, следует отметить, что данная работа учителем русского языка и литературы ведётся фрагментарно, бессистемно, о чём свидетельствует распределение часов на 
раздел «Язык и культура»: из 661 часа в примерной программе по русскому (родному) языку для основного общего образования на указанный аспект выделено всего 5 часов. Е. Быстрова отмечает: «В перспективе необходимо не предлагаемое сегодня в учебниках эпизодическое знакомство с высказываниями о богатстве, выразительности русского языка, а создание определённой системы, раскрывающей феномен отечественного языка как одной из значимых ценностей русского народа» [3, с. 9].

В практике преподавания русского языка нами была выявлена недостаточная связь между предметным содержанием и культурноязыковой компетенцией школьников, бессистемность, эпизодичность её формирования, неполнота научной разработанности исследуемой проблемы.

Анализ действующих программ и учебников подтверждает необходимость введения в школьную программу лингвокультурологического компонента, апеллирующего к когнитивным методикам. Количество часов и выбор тем для школьного изучения показывают возможность включения лингвокультурологического приращения в школьный курс.

Под лингвокультурологическим приращением мы понимаем дополнительный материал, рассматривающий взаимоотношения языка и культуры и опирающийся на основное содержание учебной программы. Так, при изучении темы «Собственные и нарицательные существительные» лингвокультурологическое приращение может быть следующим: отражение идеологем, культурных установок, стереотипов в именах собственных. Лингвокультурологические приращения не только сообщают дополнительные сведения об изучаемом лингвистическом явлении, но и актуализируют основной материал, повышают к нему интерес.

В настоящее время учитель русского языка может пользоваться несколькими программами по своему выбору. Своеобразным инвариантом содержания образования является минимум, который находит своё отражение во всех действующих программах. На этом основании для определения лингвокультурологических приращений мы обращаемся к федеральному государственному образовательному стандарту, фиксирующему содержание образования по русскому языку. Приведём возможные лингвокультурологические приращения.

При изучении темы «Общие сведения о языке»: основные лингвокультурологические сведения, культура, лингвокультура, лингвокультурная группа, языковая картина мира, представления, наивные понятия, стереотипы, эталоны, культурные установки, ( И. Ю. Токарева, 2015. 
идеологемы, концепты, архетипы, ценности; символы и эталоны; культурный код, культурная эпоха.

При изучении темы: «Введение в науку о языке»: отражение культурной информации в словаре.

При изучении темы «Фонетика. Графика»: национальные особенности звукосимволизма, критерий шибболета, обусловленность русской фонетической системы особенностями ландшафта, алфавит как система ценностей народа, нравственный потенциал славянских азбук, отражение культурных установок во внутренних формах букв.

При изучении темы «Лексика. Фразеология»: отражение культуры в лексическом значении слова, интерпретация лексического значения в категориях культуры, внутренняя форма слова (образность) и её обусловленность культурными фактами, культурная коннотация и значимость, отражение культурной информации многозначностью, омонимией, синонимией, антонимией; обусловленность лексической плотности и лакунарности системой ценностей лингвокультурной группы, квазисимволы, квазиэталоны, прецедентные единицы.

При изучении темы «Морфемика. Словообразование»: отражение актуальных для лингвокультурной общности знаний производным словом, обусловленность лексической плотности и лакунарности системой ценностей лингвокультурной группы.

При изучении темы «Имя существительное»: культурные факторы формирования категории одушевлённости, отражение идеологем, культурных установок, стереотипов в именах собственных, культурная специфика рода, культурные факторы формирования разносклоняемых существительных.

При изучении темы «Имя прилагательное»: отражение стереотипов в цветообозначениях.

При изучении темы «Имя числительное»: культурная семантика числительных, лингвокультурные причины регулярности неопределённых местоимений, культурная семантика местоимений 1-го лица.

При изучении темы «Глагол»: культурные причины продуктивности безличных глаголов, отражение представлений о времени в русской лингвокультуре.

При изучении темы «Наречие»: культурная специфика образных оснований наречий с потухшей образностью.

При изучении темы «Служебные слова»: культурная семантика частиц и междометий.

При изучении раздела «Синтаксис»: выражение представлений о $-459-$

(с) И. Ю. Токарева, 2015. 
мире с помощью словосочетания, культурные особенности синтаксической значимости, лингвокультурные причины регулярности односоставных предложений, отражение идеологем и стереотипов обращениями.

При работе с текстом: культурная обусловленность тематики и идейного содержания текста, культурная обусловленность жанров и архитектоники текста, лингвокультурные детали, интертекстуальные связи.

Перспективным для методики лингвокультурологических приращений является применение сквозных лингвокультурологических $\begin{array}{lllll}\text { тем } & \text { (термин } & \text { введён } & \text { В. Воробьёвым } & {[4, \text { c. 257]). Под }}\end{array}$ лингвокультурологической темой понимается однородный по содержанию материал. Сквозной характер предполагает, что изучение данной темы возможно в каждом классе с изменением предмета рассмотрения, акцентов изложения. Так, концепт «Родина» может быть отнесён к сквозной лингвокультурологической теме. К этому концепту можно обращаться при изучении фонетики, лексики, фразеологии, морфологии. Учитель должен предлагать учащимся языковые единицы, связанные с темой Родины, ставя на данном материале разные учебные задачи.

Для предлагаемой методики актуален концентрический подход в обучении, который предполагает дискретность учебного материала, преемственность между классами, постоянное усложнение содержания, движение от центра к периферии. При реализации концентрического подхода к первому концентру мы относим обучение русскому языку в 5-9 классах, второй концентр - в 10-11 классах. Так, одна и та же лингвокультурологическая тема может быть изучена в первом и втором концентрах. При этом матерал должен быть теоретически усложнён и эмпирически расширен. Например, если 5-м или 9-м классе (на этапе повторения) учащиеся только осмыслять, что фонетический строй языка культурно маркирован, то в 10 классе они могут познакомиться с критерием шибболета, изучить старшую и младшую орфоэпические нормы, соотнести особенности фонетической системы с особенностями ландшафта и др.

Лингвокультурологические приращения целесообразно выстаивать в виде системы эвристических упражнений и заданий, позволяющих учителю организовать работу по формированию культурно-языковой компетенции при изучении таких разделов языка, как фонетика, графика, лексикология и фразеология, морфология, синтаксис, а также при текста. Надо отметить, что в науке существуют попытки представить системы лингвокультурологических упражнений. Так, В. Тихова предлагает следующие виды способов включения лингвокультурологического материала в процесс обучения: 1) прямое включение через монолог ( И. Ю. Токарева, 2015. 
учителя; 2) расседоточенная подача родственного смежного теоретического материала; 3) опосредованно через практические материалы; 4) непосредственно через обучение способов учебных действий с языковым материалом; 5) через материалы для самоконтроля, 6) через задания к упражнениям; 7) через задания к упражнениям; 8) через тескты к самим упражнениям; 9) через материалы для внеклассного чтения [8, с. 32-33]. Несомненно, что данная классификация предствляет большой интерес для методической науки, однако, на наш взгляд, в её основе лежат разные основания, указывающие на способ действия, объект.

На наш взгляд, в системе упражнений, направленных на формирование культурно-языковой компетенции, должны преобладать задания интерпретационного типа.

Разнообразие предлагаемых нами упражнений можно свести к следующим основным видам: 1) интерпретативные (учащемуся предлагается интерпретировать предложенный материал); 2) поисковые (учащийся должен найти нужные примеры). Особым видом здесь является работа со словарями; 3) распределительные (учащийся должен распределить по группам предложенный материал); 4) сопоставительные (учащийся должен сопоставить предложенный материал); 5) моделирующие (учащийся должен создать какую-либо языковую или речевую единицу по заданным параметрам); 6) репродуктивные (учащийся должен воспроизвести заданный текст); 7) смешанные (они соединяют черты вышеназванных упражнений).

Материал, предлагаемый ко всем разделам языка, является эффективным средством оптимизации учебного процесса, актуализации интереса к родному языку, культуре, истории, культивации межпредметных связей, синтеза различных типов знаний.

Таким образом, при изучении той или иной темы по любой из действующих программ русского языка учитель может включать лингвокультурологические приращения. К культурной специфике того или иного языкового явления преподаватель может обращаться несколько раз на протяжении всего курса. Это обусловлено, во-первых, возрастными особенностями учащихся и сложностью материала, вовторых, структурированием курса: помимо основного этапа изучения факта языка, организуется повторение в конце девятого класса и в десятом-одиннадцатом классе. Предполагается также углубление знаний. Для предлагаемой методики актуален концентрический подход в обучении, который предполагает дискретность учебного материала, преемственность между классами, постоянное усложнение содержания, движение от центра к периферии. 


\section{Литература}

1. Бирюкова Т. Г. Роль культурно-языковой подготовки учащихся в современном обучении русскому языку / Т. Г. Бирюкова // Язык как система и деятельность. Материалы всероссийской научной конференции, посвящённой 80-летию со дня рождения профессора А. Н. Тихонова. - Ч. 2. - Елец : Из-во ЕГУ, 2011. - С. 224-230.

2. Болотнова Н. С. Методика концептуального анализа поэтического текста и её использование в вузе и в школе / Н. С. Болотнова // Преподавание русского языка в школе и вузе в контексте межкультурной коммуникации / под ред. А. Д. Дейкиной и др. - М. : МАГУ ; Ярославль : РЕМДЕР, 2010. - С. 248-256.

3. Быстрова Е. А. Аксиологический подход в преподавании русского языка в современной школе / Е.А. Быстрова // Аксиологические аспекты методики преподавания русского языка (профессиональный и общеобразовательный уровни) / под ред. А. Д. Дейкиной и др. - М. : Из-во МАГУ ; Ярославль : РЕМДЕР, 2009. - С. 7-9.

4. Воробьёв В. В. Лингвокультурология : [монография] / В. В. Воробьёв. - М. : Российский университет дружбы народов, 2008. - 336 с.

5. Гудков Д. Б. О русском языке и не только о нём / Д. Б. Гудков, Е. Ю. Скороходова. - М. : Гнозис, 2010. - 206 с.

6. Дейкина А. Д. Проблематика монографии и её современное звучание / А. Д. Дейкина // Духовно-нравственное воспитание учащихся при обучении язику : слово - история - искусство. - М. : МПГУ, Ярославль : Ремдер, 2013. - С. 10-11.

7. Новикова Л. И. Культуроведческий аспект обучения русскому языку в 5-9-х классах как средство постижения учащимися национальной культуры : дис. ... д-ра пед. наук : 13.00.02 / Л. И. Новикова. - М., 2005. - 515 с.

8. Тихова В. В. Формирование духовно-нравственных ценностей страшеклассника : на пути к осознанию менталитетных свойств русской языковой личности (к постановке проблемы) / В. В. Тихова // Духовно-нравственное воспитание учащихся при обучении языку: слово - история - искусство. - М. : МАГУ ; Ярославль : Ремдер, 2013. - C. 29-34.

9. Филиппова О. В. Изучение национально-культурного коммуникативного идеала в процессе развития речевой индивидуальности учащихся / О.В. Филиппова Г. В. Кашаева // Теоретические и прикладные проблемы лингвокультурологии. - Тула : Тульский полиграфист, 2009. -С.175-179.

10. Ляпина И. Р. Применение маркетинговых исследований при формировании компетентностной модели випускника / М. И. Суганова, И. Р. Ляпина // Известия ТулГУ. Гуманитарные науки. - Вып. 3. - Ч. 2. - 2013. - С. 160-166.

Стаття надійшла до редакиії 01.07.2015 p. 